\title{
The History and Driving Force for Prehistoric Human Expansion Upward to the Hinterland of the Tibetan Plateau Post-Last Glacial Maximum
}

\author{
Guangliang Hou ${ }^{1}$, Weimiao Dong ${ }^{2, *}$, Linhai Cai ${ }^{3}$, Qingbo Wang ${ }^{1}$ and Menghan Qiu ${ }^{4, *}$ \\ 1 Academy of Plateau Science and Sustainability, Qinghai Normal University, Xining 810016, China; \\ hg120@163.com (G.H.); w18217350959@163.com (Q.W.) \\ 2 Department of Cultural Heritage and Museology \& Institute of Archaeological Science, Fudan University, \\ Shanghai 200433, China \\ 3 Qinghai Provincial Institute of Cultural Relics and Archaeology, Xining 810007, China; lhcai00@163.com \\ 4 Key Laboratory of Western China's Environmental Systems (Ministry of Education), College of Earth and \\ Environmental Sciences, Lanzhou University, Lanzhou 730000, China \\ * Correspondence: dongwm@fudan.edu.cn (W.D.); choumh14@lzu.edu.cn (M.Q.); \\ Tel.: +86-177-2128-0080 (W.D.); +86-186-1849-4906 (M.Q.)
}

Citation: Hou, G.; Dong, W.; Cai, L.; Wang, Q.; Qiu, M. The History and Driving Force for Prehistoric Human Expansion Upward to the Hinterland of the Tibetan Plateau Post-Last Glacial Maximum. Sustainability 2021, 13, 7065. https://doi.org/10.3390/ su13137065

Academic Editor: Harry F. Lee

Received: 22 March 2021

Accepted: 18 June 2021

Published: 23 June 2021

Publisher's Note: MDPI stays neutral with regard to jurisdictional claims in published maps and institutional affiliations.

Copyright: (c) 2021 by the authors. Licensee MDPI, Basel, Switzerland. This article is an open access article distributed under the terms and conditions of the Creative Commons Attribution (CC BY) license (https:// creativecommons.org/licenses/by/ $4.0 /)$.

\begin{abstract}
The timing and motivation of prehistoric human expansion into the hinterland of the Tibetan Plateau (TP) is a widely debated scientific issue. Recent archaeological studies have brought forward predictions of the earliest human occupation of the TP to the late-Middle Pleistocene. However, massive human occupation of the TP did not appear until the termination of the Last Glacial Maximum (LGM). The spatio-temporal distribution of prehistoric hunter-gatherers on the TP varies significantly before the permanent occupation after 3600 BP (before present). Here, we report on environmental-archaeological evidence from the Canxionggashuo (CXGS) site in Yushu Prefecture, which provides information that is key to understanding the dynamics of post-LGM human occupation on the TP. Radiocarbon dating has revealed two occupation periods of the CXGS site at 8600-7100 cal (calibrated years) BP and 2400-2100 cal BP. The charcoal concentration in cultural layers correlates well with paleo-human activities. Hunter-gatherers expanded westwards from the northeastern margin of the TP to the hinterland of the TP during the warming period of the early-middle Holocene ( 11,500-6000 BP). However, these groups retreated during the middle-late Holocene ( 6000-3600 BP) under a cooling-drying climate. Prehistoric humans finally occupied the hinterland of the TP permanently after $3600 \mathrm{BP}$, with an enhanced cold-adaptive lifestyle, although the climate was still deteriorating.
\end{abstract}

Keywords: the Holocene; Tibetan Plateau; late Paleolithic; climate change; human occupation; subsistence strategy

\section{Introduction}

Areas of high altitude present a major challenge for human occupation given the extreme cold, scarce food resources, and physiological stress caused by a low oxygen concentration. The Tibetan Plateau (TP), as the largest and highest plateau on Earth, also called the Third Pole, was one of the most challenging areas for prehistoric humans to conquer. For the hinterland of the TP in particular, where the altitude is above $4000 \mathrm{~m}$, the severe environment makes it one of the harshest areas for human occupation [1]. As such, the TP has become a key area for studying the history of human migration from lowlands to highlands [2-4]. According to the National Archaeological Survey in China, thousands of prehistoric archaeological sites have been found on the TP [5,6], distributed across a wide altitudinal range ( 1700-5000 $\mathrm{m}$ a.s.l.) [7], and this has laid the foundation for further research. The initial timing, dynamic, and motivation for prehistoric human exploration 
and occupation of the TP has become a hot scientific issue in recent decades, drawing the attention of multiple disciplines.

Archaeological and genetic studies provide valuable clues for exploring the trajectory of prehistoric human migration to the TP from surrounding areas [8-14]. However, the history of prehistoric human occupation on the TP is still highly debated, especially as regards the timing of the initial human exploration and their permanent settlement on the TP [15-17], as well as the routes of early human expansion to the hinterlands of the TP $[18,19]$. Recent studies have traced the initial prehistoric human exploration of the TP back to pre-Last Glacial Maximum (LGM, 26,500-18,000 BP, BP stands for before present). Ancient humans began to explore the marginal zone and high-altitude hinterlands of the TP no later than 160,000 BP and during 40,000-30,000 BP, respectively, according to the excavations and studies of the Baishiya Karst Cave site (3280 m a.s.1.) $[20,21]$ and the Nwya Devu site (4600 m a.s.1.) [22]. Confirmed by genetic studies [11,13], these could be the periods in which the first ancient humans explored the TP. However, these studies provide isolated evidence for early human activity on the $\mathrm{TP}$, raising more questions about the patterns and driving forces of prehistoric human expansion into the TP, which thus requires further case studies. Nevertheless, prehistoric humans expanded extensively into the TP post-LGM and occupied the hinterland of the TP during the warming Holocene.

The spatial distribution of Paleolithic, Neolithic and Bronze Age sites on the TP provides valuable archives from which to derive the patterns of prehistoric human expansion into the high plateau during the prehistoric period. However, most prehistoric sites on the TP lack definitive dating. The estimation of age based on the features of artefacts, such as stone tools, pottery fragments and bronze vessels, has recently attracted more attention [23-25]. Therefore, the dating of cultural sediment that contains archaeological remains provides more reliable and higher-resolution chronology, which gives a more accurate timing of these human settlements on the TP, especially for the high-altitude hinterland $[19,25]$.

Besides the issues of reliable chronology, the motivation for prehistoric humans to expand into the hinterland of the TP is also unknown. Favorable climatic conditions have been cited as the most important factor, promoting the occupation of the TP by huntinggathering groups during the Late Paleolithic [26,27], as well as the settlement of the upper Yellow River valley during the Neolithic period [28,29]. In contrast, prehistoric groups extensively and permanently settled the areas above $2500 \mathrm{~m}$ a.s.l. on the TP after $3600 \mathrm{BP}$ under a cooling climate, which was thought to be primarily facilitated by the adoption of a cold-tolerant agro-pastoral livelihood [15]. The extent to which prehistoric human occupation of the hinterland of the TP was facilitated by climatic conditions or changing subsistence strategies has not yet been clearly established.

To resolve the problems above, we refined the chronology and analyzed archaeological remains, as well as charcoal concentrations, in sediments of Canxionggashuo (CXGS, also known as Tshem Gzhung Kha Thog (TGKT) according to its Tibetan pronunciation), an early-middle Holocene Paleolithic site where plenty of microblade lithic tools and animal bone fragments were unearthed during the archaeological excavation [30]. On the basis of this, we reviewed the archaeological discoveries from the TP and compared them to the paleoclimatic records to reveal the history and possible driving forces for prehistoric human occupation of the hinterland of the TP. This work provides valuable data and insights for improving the models of prehistoric human expansion into the TP and understanding the dynamics for different groups (hunter-gatherers, farmers, and nomads) expanding upward into the hinterland of the TP.

\section{Study Area}

Yushu Autonomous Prefecture is located in Qinghai Province, east-central TP, and lies at an average altitude of $\sim 4500 \mathrm{~m}$, as shown in Figure 1a. Except for some valleys in the east, most of Yushu is above $4000 \mathrm{~m}$ a.s.l., making this area a key station along the Tang-Tibet Ancient Road, also known as the Tang-Tubo Passage, which was one of the most important 
passageways of human migration from the lowland to the high-altitude hinterland of the TP. Dozens of prehistoric sites have been discovered in this area [5]. According to the features of pottery shards exposed at the surface, a group of archaeological sites have been identified as belonging to the Late Neolithic or Bronze Age [5]. However, a recent chronological study indicated that most of these sites were settled within the common era, while only the Gala site beside the Tongtian River was dated to 2700 cal (calibrated years) BP [25]. In some sites of the Yushu area, only portable microblade lithic artefacts were found, suggesting highly mobile hunting-gathering people might have occupied the area much earlier [30].

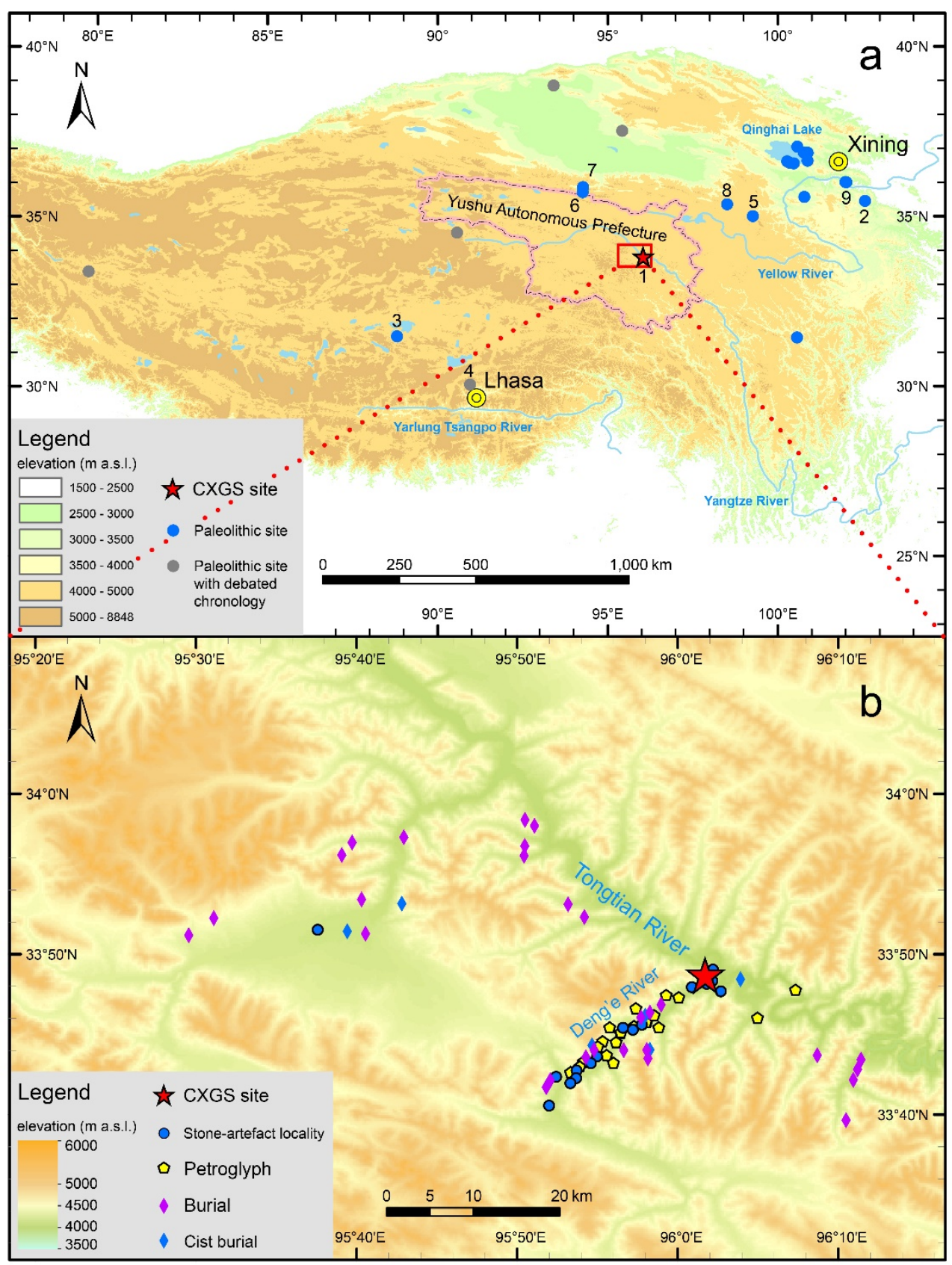

Figure 1. (a) Canxionggashuo (CXGS) site and other Paleolithic sites of chronological study on the Tibetan Plateau (TP). The sites mentioned in this paper are labeled as follows: 1. CXGS, 2. Baishiya Cave, 3. Nwya Devu, 4. Qiusang, 5. Xiadawu, 6. Xidatan, 7. Yeniugou, 8. Donggi Cona, 9. Shalongka. (b) archaeological remains around the CXGS site according to the archaeological investigations. 
Tongtian River is another name for the upper reaches of the Yangtze River in Yushu Prefecture. The drainage basin of Tongtian River lies at an average altitude of $\sim 4200 \mathrm{~m}$, resulting in a low oxygen content (the atmospheric pressure at $4500 \mathrm{~m}$ a.s.l. is usually half the pressure at sea level), severe cold, and poor natural productivity. The annual mean temperature in this area is below $0{ }^{\circ} \mathrm{C}$, while annual precipitation ranges from 270 to $410 \mathrm{~mm}$. Glaciers and lakes are prevalent in the upper reaches. The most common vegetation types in this area are subalpine steppe and alpine steppe (Type "ET" in KöppenGeiger's classification) [31]. The modern population density in the Tongtian River basin is extremely low (less than one person per $\mathrm{km}^{2}$ ), a result of the harsh living environment. The Tongtian River valley has thus been described as one of the most difficult areas of the TP for humans to settle [32]. Modern people in Yushu primarily raise sheep and yak, while the cultivation of crops (especially naked barley) is auxiliary to their livelihood [33].

The CXGS site ( $33^{\circ} 48^{\prime} 16^{\prime \prime} \mathrm{N}, 96^{\circ} 02^{\prime} 35^{\prime \prime} \mathrm{E}, 4016 \mathrm{~m}$ a.s.l.) is located in Zhiduo County, Yushu Prefecture. As shown in Figure 1b, the archaeological site sits on a small tableland near the confluence of Tongtian River and its first tributary, the Deng'e River in the east. The site was discovered during a regional archaeological investigation in 2013-2015. Plenty of archaeological remains, including burials, petroglyphs, and stone artefact localities, were discovered during the investigation, indicating prosperous regional human activity in prehistoric times. The CXGS site was then systematically excavated by archaeologists, and revealed to be an 8200-7100 cal BP Paleolithic hunter-gatherer's workshop. Details of the process of excavation, the layering of deposition, and the features of the stone artefacts have been well reported [30]. Moreover, a study of the typology and technology of the lithic artefacts revealed the CXGS site to be a lithic workshop organized by a group living in a high-altitude region nearby, given the logistical mobility and the distance to other reported Paleolithic sites [30].

\section{Materials and Methods}

To investigate the history of human activity at the CXGS site and its impact on the environment, a $1.5 \mathrm{~m} \times 0.5 \mathrm{~m}$ trench was chosen according to its high concentration of stone artefacts. Afterwards, a $103 \mathrm{~cm}$ depth profile was obtained for sampling. The profile was divided into five layers, with layer 4 assigned three sublayers according to the texture of the sediment and the cultural remains buried (see Table 1 and Figure $2 \mathrm{a}$ for detail). The $0-18 \mathrm{~cm}$ layer is topsoil, disturbed by modern human activities and surface vegetation. A sandy clay layer was found at $18-25 \mathrm{~cm}$ under the topsoil. The soil found at a $25-58 \mathrm{~cm}$ depth consists of silty clay and contains a few cultural remains. The silty clay layer at 58-103 cm can itself be divided into three sublayers. These sublayers contain abundant stone artefacts and a few animal bone fragments. Layer 5, beneath $103 \mathrm{~cm}$, consists of uninterrupted red clay, and human remains could not be seen in this layer, where our excavation and sampling terminated.

Table 1. Profile layer delamination, description of sediment texture and cultural remains.

\begin{tabular}{|c|c|c|c|c|}
\hline Layer & Depth (cm) & Texture & Properties & Cultural Remains \\
\hline I & $0-18$ & Topsoil & Brown gray, loose, granulated & None \\
\hline II & $18-25$ & Sandy clay & Gray, poor cohesion, rough & None \\
\hline III & $25-58$ & Silty clay & $\begin{array}{l}\text { Dark gray, weak cohesion, with } \\
\text { fine particles }\end{array}$ & $\begin{array}{c}\text { A few stone artefacts and animal } \\
\text { bone fragments }\end{array}$ \\
\hline IV-1 & $58-74$ & Silty clay & Yellowish, weak cohesion & $\begin{array}{l}\text { Abundant stone artefacts and a } \\
\text { few animal bone fragments }\end{array}$ \\
\hline IV-2 & $74-89$ & Silty clay & Gray & Same as IV1 \\
\hline IV-3 & 89-103 & Silty clay & Blackish, uniform & Same as IV1 \\
\hline $\mathrm{V}$ & $>103$ & Clay & Red, uniform & None \\
\hline
\end{tabular}




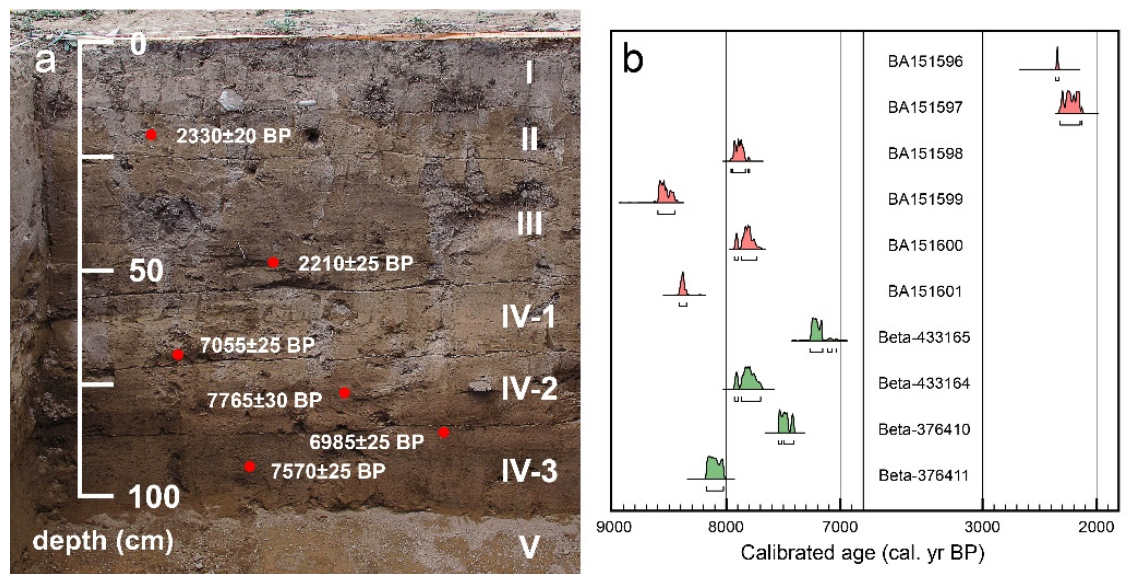

Figure 2. Profile and radiocarbon dating results for the CXGS site. (a) Profile of CXGS site labeled with sedimental layers and radiocarbon dating samples. Note that Layer V was not fully exposed due to the termination of our excavation. (b) Calibrated radiocarbon dating results of the CXGS site, with frequency curves in red representing data from this study, and curves in green representing data of a previous study [30].

Charcoal samples from different layers (see Figure 2) were sent to the Peking University Radiocarbon Laboratory for radiocarbon dating so as to determine the chronology of the profile. These charcoal samples consist of charred wood debris, but the species of wood have not been identified. The samples were pretreated with a standard acid-alkali-acid pretreatment and sent for accelerator mass spectrometry (AMS) for ${ }^{14} \mathrm{C}$ measurement. The raw dating results were calibrated with OxCal 4.4 software [34] with an up-to-date IntCal20 curve [35].

Sediments of the profile were sampled at $5 \mathrm{~cm}$ intervals, starting from $20 \mathrm{~cm}$ for water sieving, thus excluding the topsoil. Bone fragments and stone artefacts that had sunk to the bottom were collected for statistical analysis. Since animal bones and various stone artefacts are some of the most common cultural relics found at hunting-gathering Paleolithic sites, the remains found at different depths were calculated, with the intension of revealing the variation in intensity of human activity at the CXGS site. Another sequence taken at $2 \mathrm{~cm}$ intervals from the profile was sampled for environmental analysis-specifically, charcoal concentration.

Charcoal concentration is a good indicator of the intensity of paleofire events, including both natural fires and human activities [36-38]. The transmission distance of charcoal is strongly associated with its particle size. For instance, the vast majority of charcoal particles $>125 \mu \mathrm{m}$ were found to have settled within a $7 \mathrm{~km}$ range [39], and this is typical for local fire events [38,40]. Charcoal of 50-125 $\mu \mathrm{m}$ particle size is conventionally regarded as an indicator of regional (tens-hundreds of kilometers) fire events, whilst charcoal $<50 \mu \mathrm{m}$ is an indicator of larger-scale (usually $>10^{3} \mathrm{~km}$ ) fire events [39]. Charcoals used for concentration measurement were acquired via heavy liquid flotation and were assessed via sampling statistics to acquire the charcoal concentration index [41]. Charcoals were floated in a zinc diiodide $\left(\mathrm{ZnI}_{2}\right)$ liquid and separated. A lower limit of $20 \mu \mathrm{m}$ for charcoal particle size was adopted during the calculation.

\section{Results}

\subsection{Chronology}

The AMS ${ }^{14} \mathrm{C}$ dating results for the CXGS site are listed in Table 2 and Figure 2, including data from both the excavation [30] and the profile of this study. Age inversion occurs at the $45-50 \mathrm{~cm}$ and $75-80 \mathrm{~cm}$ depths, which may result from the disturbance of the stratum. However, these AMS ${ }^{14} \mathrm{C}$ ages can still be taken to indicate two distinct periods of human activity during the early-middle Holocene and the late Holocene, 8600-7700 cal BP (BA151598-151601), and 2400-2100 cal BP (BA151596-151597), respectively. Combined 
with the dating results from the excavation [30], we can infer the early period of the CXGS site to extend to $8600-7100 \mathrm{cal} \mathrm{BP}$.

Table 2. Accelerator mass spectrometry (AMS) ${ }^{14} \mathrm{C}$ dates from the profile of this study and during the excavation [30] of the CXGS (or Tshem Gzhung Kha Thog, TGKT) site.

\begin{tabular}{|c|c|c|c|c|c|}
\hline Lab Code & Depth (cm) & Material & $\begin{array}{c}\text { AMS }{ }^{14} \text { C Age } \\
\text { (Before Present, BP) }\end{array}$ & $\begin{array}{l}\text { Calibrated Age } 2 \sigma \\
\text { (cal BP) }\end{array}$ & Reference \\
\hline BA151596 & 21 & Charcoal & $2330 \pm 20$ & $2360-2330$ & This study \\
\hline BA151597 & $45-50$ & Charcoal & $2210 \pm 25$ & $2330-2120$ & This study \\
\hline BA151598 & $65-70$ & Charcoal & $7055 \pm 25$ & 7960-7790 & This study \\
\hline BA151599 & $75-80$ & Charcoal & $7765 \pm 30$ & $8600-8450$ & This study \\
\hline BA151600 & $85-90$ & Charcoal & $6985 \pm 25$ & $7930-7730$ & This study \\
\hline BA151601 & 95 & Charcoal & $7570 \pm 25$ & $8420-8340$ & This study \\
\hline Beta-433165 & Layer 2 & Bone & $6270 \pm 30$ & $7270-7030$ & [30] \\
\hline Beta-433164 & Layer 3 & Bone & $6980 \pm 40$ & $7930-7690$ & [30] \\
\hline Beta-376410 & Layer 5 & Charcoal & $6590 \pm 30$ & $7570-7420$ & [30] \\
\hline Beta-376411 & Layer 5 & Charcoal & $7290 \pm 30$ & $8180-8020$ & [30] \\
\hline
\end{tabular}

\subsection{Indicators of Human Activity}

Relics closely related to human activities, including stone artefacts and animal bones, were extracted from the sediment samples (see Figure 3). Animal bones were abundant at depths of 35-55 cm and 85-95 cm. In particular, six pieces of animal bone fragment were found in the $45-50 \mathrm{~cm}$ layer, as shown in Figure $3 \mathrm{~b}$. Stone artefacts were present at all depths of the cultural layer $(20-95 \mathrm{~cm})$, but were most abundant between 65 and $75 \mathrm{~cm}$, with 19 flake debitages and 15 microblades deposits at the $65-70 \mathrm{~cm}$ depth, and 33 flake debitages and 15 microblades deposits at the 70-75 cm (Figure 3c-e). Flake debitages were consistently distributed at 20-95 cm, while microblades only appeared at $40-80 \mathrm{~cm}$ (Figure 3c,e). The features of the stone artefacts at the CXGS site were systematically studied after the excavation [30], and found to be closely related to the discoveries in other Paleolithic sites on the northeastern Tibetan Plateau (NETP) such as Xidatan [42], Shalongka [43], Xiadawu [44], and Donggi Cona [45,46].

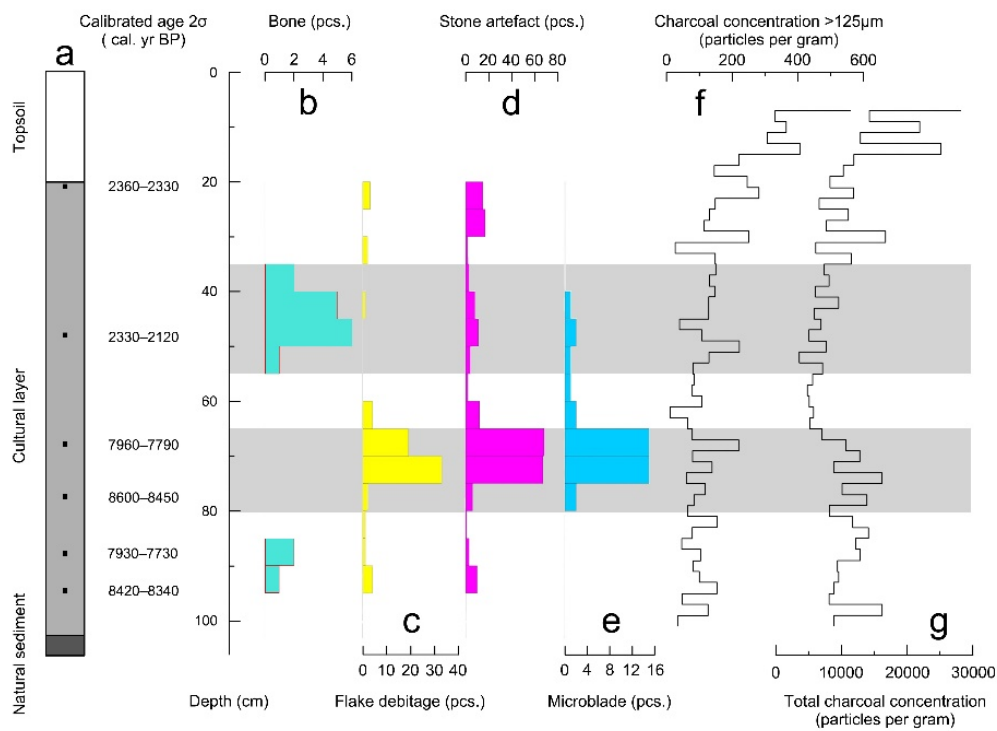

Figure 3. Cultural remains and charcoal concentrations of the CXGS profile. (a) Stratigraphic column with radiocarbon dates; (b) count of animal bone fragments; (c) count of flake debitages; (d) total count of stone artefacts; (e) count of lithic microblades; (f) concentration of charcoal >125 $\mu \mathrm{m}$; (g) total charcoal concentration. 


\subsection{Variation of Charcoal Concentration}

The variation of charcoal concentration in the CXGS profile shows a similar tendency between the all-sized particles and particles $>125 \mu \mathrm{m}$ (Figure 3f,g). There are two areas of high charcoal concentration, at $10-55 \mathrm{~cm}$ and $65-100 \mathrm{~cm}$, separated by a gap at $55-65 \mathrm{~cm}$. This indicates that fire events occurred frequently around the CXGS site during 8600-7700 cal BP and 2400-2100 cal BP, which correlated well with the distribution of cultural remains. As for the continuous increase in charcoal concentration in the upper part $(10-30 \mathrm{~cm})$ of the profile, this may have been influenced by modern human activities.

\section{Discussion}

\subsection{History for Prehistoric Human Expansion upward to the Hinterland of Tibetan Plateau}

Humans definitely occupied the margin of the high-altitude hinterland of the eastcentral TP in Yushu during 8600-7100 cal BP and $2400-2100 \mathrm{cal}$ BP (Figure 2 and Table 2), as indicated by the AMS ${ }^{14} \mathrm{C}$ dates from the strata at the CXGS site, where archaeological remains, including animal bones and stone artefacts, were unearthed (Figure 3). Charcoal concentration in sediment is an effective index for the extent of paleofire as related to climate change or human activities [37,47], wherein charcoals $>125 \mu \mathrm{m}$ in particle size are suggested to be mainly produced by local paleofire events [40]. The concentrations of both all-sized and $>125 \mu \mathrm{m}$ charcoals in the two cultural layers $(20-55 \mathrm{~cm}$ and $65-100 \mathrm{~cm})$ of the CXGS site are obviously higher than in the 55-65 cm layer, corresponding with the distribution of archaeological remains. Thus, the high concentration of charcoal is more likely to be anthropogenic, originating from such sources as campfires, which further suggests that prehistoric humans inhabited the region around the CXGS site in these two periods.

Our study is consistent with recent archaeological investigations and dating work carried out in the Yushu area [25,30], indicating that humans permanently occupied this marginal zone of the high-altitude hinterland of the TP in the third millennium BP. The dating results of the CXGS site (Table 2) suggest initial human occupation in the Yushu area as early as $~ 8600$ BP. Dozens of Late Neolithic and Bronze Age sites have been reported in this area [5]. However, whether human occupation of the Yushu area in 7100-2700 BP actually occurred needs to be further examined via excavation and dating work. Preliminary dating work has suggested most sites were occupied after the initiation of the common era $[14,25]$. At the same time, the existence of low-intensity human settlements in Yushu and other high-altitude hinterlands during the middle-late Holocene ( 6000-3600 BP) cannot be denied, especially considering the insufficiency and inaccuracy of chronological data in many archaeological sites.

Nevertheless, massive human expansion into and occupation of the TP occurred after the LGM, which is much later than the pioneers such as the Denisovans and the Nwya Devu group [20-22]. Previous archaeological studies on the TP indicated that prehistoric humans undoubtedly occupied the marginal zone of the hinterland of the TP since the middle Holocene [42,48]. Although some scholars argue that hunter-gatherers might have expanded into the high-altitude hinterland much earlier, the chronology of these key Paleolithic sites is still debatable. For example, some scholars propose that foragers occupied the Qiusang site (4270 m a.s.l.) near Lhasa in Tibet at 21,000 BP [49], while some others refute this and argue that humans probably occupied the site during the early Holocene ( 8400-7400 cal BP) [16]. However, these dating results have been questioned due to either the method [50] or the absence of reliable cultural layers [51]. Restricted by reliable stratigraphic information, the oldest Paleolithic sites post-LGM near or above $4000 \mathrm{~m}$ a.s.l. on the TP are Xiadawu ( 11,200 cal BP, $3988 \mathrm{~m}$ a.s.l.) [44] and Xidatan ( $7200 \mathrm{cal} \mathrm{BP}, 4300 \mathrm{~m}$ a.s.l.) [42], while other well dated prehistoric sites above $4000 \mathrm{~m}$ a.s.1. include Donggi Cona (5800-5000 cal BP, $4136 \mathrm{~m}$ a.s.l.) [45,46], Jiaritang (3200-2900 cal BP, $4311 \mathrm{~m}$ a.s.1.) [52] and Piyang-Donggar (2725-2170 cal BP, $4139 \mathrm{~m}$ a.s.l.) [53].

To understand the trajectory of prehistoric human extension into the hinterland of the $\mathrm{TP}$, a clarification of the history of stepwise expansion from low-altitude to high-altitude 
areas of the TP is essential. Some models of prehistoric human colonization on the TP have been proposed basing on archaeological evidence $[8,10,15,19]$. However, archaeological studies have been updated in recent years, and this study provides more valuable clues to understanding the pattern of prehistoric occupation of Tibet in prehistoric times, as shown in Figures 4 and 5.

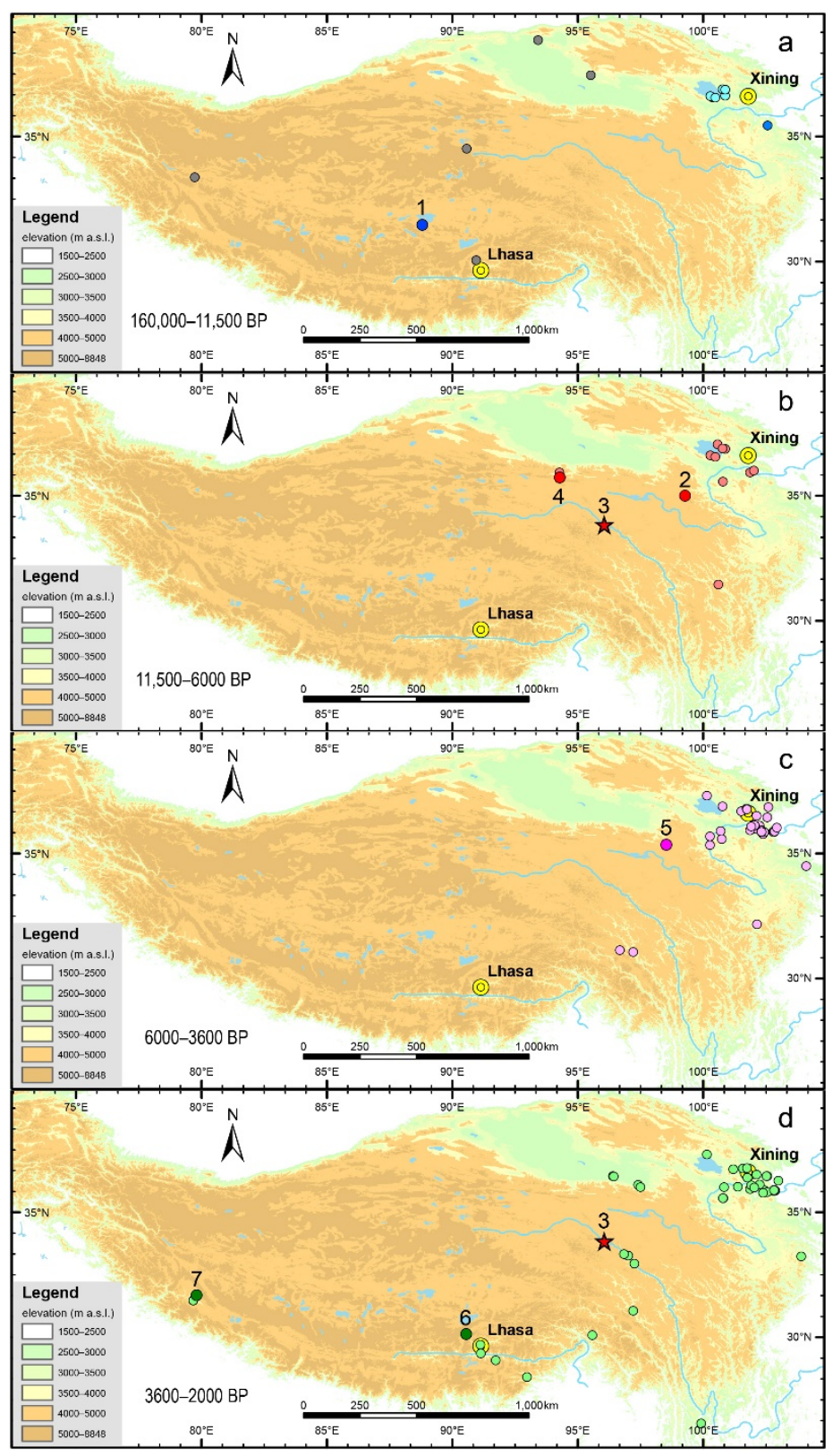

Figure 4. Spatial and temporal distribution of prehistoric archaeological sites on the TP, divided into four stages: (a) 160,000-11,500 BP, with blue dots representing sites before the Last Glacial Maximum (LGM), cyan dots representing sites post-LGM but before 11,500 BP, and gray dots representing Paleolithic sites with debated chronology; (b) 11,500-6000 BP, where red dots represent sites of this period, and the CXGS site is marked with a red star; (c) 6000-3600 BP, where pink dots represent sites of this period; (d) 3600-2000 BP, where green dots represent sites of this period, while the CXGS site is marked with a red star. Archaeological sites with reliable chronology near or above $4000 \mathrm{~m}$ a.s.l. are labeled as follows: 1. Nwya Devu (4600 m a.s.1.), 2. Xiadawu (3988 m a.s.1.), 3. CXGS (4016 m a.s.1.), 4. Xidatan (4300 $\mathrm{m}$ a.s.l.), 5. Donggi Cona (4136 m a.s.l.), 6. Jiaritang (4311 m a.s.1.), 7. Piyang-Donggar (4139 $\mathrm{m}$ a.s.l.). 


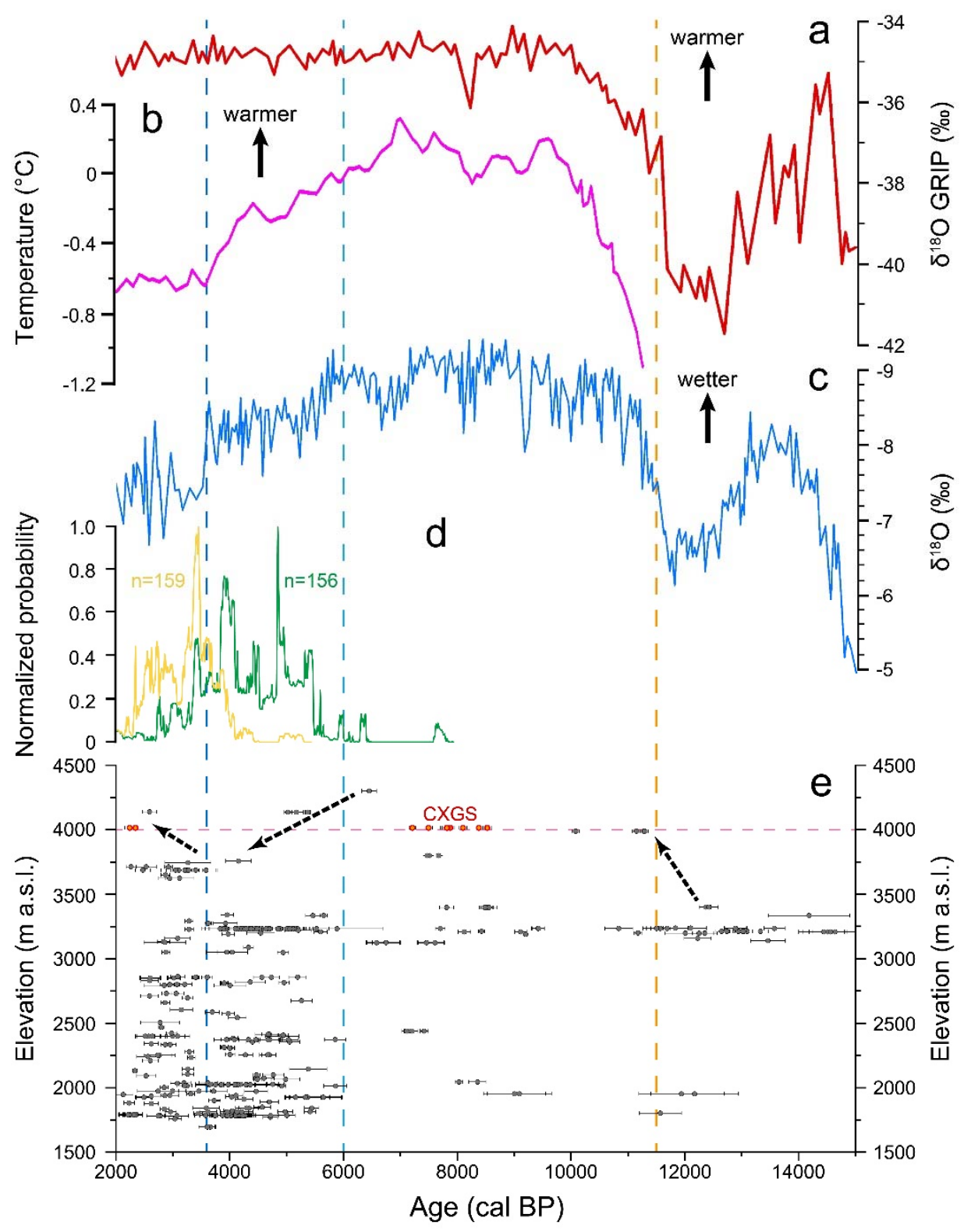

Figure 5. Comparison of paleoclimate records, crop utilization in China, and altitudinal variation in human activity on the TP during 15,000-2000 cal BP. (a) $\delta^{18} \mathrm{O}$ record from Greenland ice core indicating global temperature changes [54]; (b) reconstruction of the temperature variation in the Northern Hemisphere during the Holocene [55]; (c) $\delta^{18} \mathrm{O}$ record for the intensity of Asian monsoon derived from Dongge Cave, China [56]; (d) normalized summed probability density curve constructed from published radiocarbon dates of millet remains (in green) and wheat or barley remains (in yellow) from China (Table S1) [15,57-92]; (e) altitudinal variation in prehistoric human activity on the TP constructed from radiocarbon ages, where red dots represent the CXGS site.

Hunter-gatherers started to explore the TP before the LGM [20-22]. As regards the more massive expansion into and occupation of the TP post-LGM, foragers definitely occupied areas above $3200 \mathrm{~m}$ a.s.l. in the Qinghai Lake basin of the NETP from 14,600 cal BP [2], after which they mainly engaged in hunting-gathering in the area (Figure 4a). Paleolithic groups continued to occupy the Qinghai Lake basin during the Younger Dryas $(\sim 12,900$ 11,600 BP), while the lower-altitude areas with elevation between 1700 and $2000 \mathrm{~m}$ a.s.l. in Yunnan Province in the southeastern Tibetan Plateau (SETP) and Gansu Province in the western Loess Plateau were also occupied [93-95]. 
The range of hunting-gathering gradually expanded towards the high-altitude hinterland of the central TP during the early-middle Holocene, reaching the Xiadawu site (3988 $\mathrm{m}$ a.s.1.) in Guoluo Prefecture at 11,000 cal BP [44], the CXGS site (4016 m a.s.l.) in Yushu Prefecture in 8600-7100 cal BP [30], and the Xidatan (4300 $\mathrm{m}$ a.s.l.) and Yeniugou sites (3800 m a.s.l.) in the Kunlun Pass in 7500-7200 cal BP [42,48]. The living space and intensity of hunting-gathering groups on the TP increased in 11,500-6000 BP compared to previous periods, and humans colonized different altitudinal regions of the TP during this period (Figures $4 \mathrm{~b}$ and $5 \mathrm{e}$ ). The feature of artefacts in these sites have shown similarities to those from contemporaneous sites in the Qinghai Lake basin and the upper Yellow River valley $[4,48]$, suggesting hunting-gathering groups might have expanded to the high-altitude hinterland of the TP from the NETP.

However, in 6000-3600 BP, the distribution range of prehistoric sites on the TP shrank remarkably in comparison to the former period (Figure $4 b, c)$. Prehistoric humans mainly occupied areas below $3500 \mathrm{~m}$ a.s.l. in the eastern margin of the plateau, although huntergatherers still appeared around Donggi Cona lake (4136 m a.s.l.) in the Guoluo Prefecture in $5800-5000 \mathrm{cal} \mathrm{BP}$ (Figures $4 \mathrm{c}$ and 5e) [45,46]. However, the intensity of human inhabitation in low-altitude regions of the NETP markedly increased during the 5500-3600 BP period, and hundreds of Neolithic sites have been found in the valleys of the upper Yellow River and Yangtze River $[5,6,96,97]$. This indicates that agricultural groups extensively occupied the low-altitude NETP in this period. Meanwhile, indigenous hunting-gathering groups might also have co-existed with incoming new farming groups, such as the Zongri group in NETP [98] and the Karuo group in SETP [99].

The domain of prehistoric humans on the TP expanded unprecedentedly in 3600-2000 BP $[15,100]$. As shown in Figure 4d, Prehistoric humans expanded into the hinterland of the $\mathrm{TP}$, and especially into areas such as the upper Yarlung Tsangpo River valley in south $\mathrm{TP}$, and Yushu in east-central TP. Nevertheless, the sources of Bronze Age groups on the hinterland of TP might be complex. Plenty of cemeteries and petroglyphs have been found in the Yushu area, such as in the Deng'e River valley, as shown in Figure 1b. A special kind of burial, cist burials (stone slab tombs), were also identified in the eastern margins of the TP, including Gansu, eastern Qinghai, western Sichuan and northern Yunnan. These burials were suggested to be $\sim 1000-2000$ years older than those in the Yushu area [101]. However, pottery fragments from the Yushu area have similar features to those discovered from the Bronze Age Kayue Culture ( 3600-2300 cal BP) in the NETP [25]. In particular, the grey ceramic amphoras with two big handles are extremely similar to the Tangwang Type ( 2700-2500 cal BP) from the Kayue Culture [102]. This indicates that humans might have migrated to the east-central TP from different regions of the eastern margin of the TP.

\subsection{The Factors Promoted Prehistoric Human Expansion upward into the Hinterland of the Tibetan Plateau Post-Last Glacial Maximum (LGM)}

The severe environmental conditions during LGM seem to have been a primary factor preventing ancient humans from exploring the hinterland of the TP, although the climate conditions may have been slightly diverse in different regions of the TP [103]. The earliest evidence of human occupation in areas above $4000 \mathrm{~m}$ a.s.l. post-LGM comes from the Andes Mountains. Humans settled in areas above $4300 \mathrm{~m}$ a.s.l. in 12,800-11,500 BP under a relatively cold climate [104], but the motivation for this remains unclear. Humans carried on accessing the highlands above $4000 \mathrm{~m}$ a.s.l. in the Andes in 9000-6000 BP, mainly driven by favorable climatic-environmental conditions [105]. These case studies suggest that natural factors contributed significantly to humans living on highlands in the prehistoric period, which offers insight into the factors behind prehistoric human expansion towards the hinterland of the TP.

What encouraged prehistoric humans to migrate upward into the high-altitude hinterland of the TP is a scientific issue of great interest, and it has been intensively discussed in recent years $[10,15,16,19,22]$. Some scholars have argued that climate change was the major factor influencing human migration onto the TP $[26,27,106]$, while others propose that technical innovation, such as agricultural evolution, allowed humans to settle year- 
round on a large scale in areas above $2500 \mathrm{~m}$ a.s.l. post-3600 BP [15]. Some scholars have also suggested that the primary factor promoting the occupation of the TP by prehistoric humans varied in different periods [19], which might also elucidate the factors influencing prehistoric human expansion into the hinterlands of the TP. However, the existing archaeological evidence remains insufficient, demanding further excavation and dating work be carried out on Paleolithic sites on the TP to clarify the spatio-temporal patterns of human occupation in the high-altitude hinterland of the TP.

We now know that human occupation of the TP in 15,000-6000 BP was primarily influenced by climatic and environmental changes, as inferred from the comparison between archaeological and paleoclimatic evidence (shown in Figure 5). Humans have occupied the Qinghai Lake basin since 14,600 cal BP [2], which corresponds to the termination of the LGM and the onset of a wetting and warming climate [107] during the Bølling-Allerød interval ( 14,600-12,900 BP). The tree pollen concentration in Qinghai Lake sediment reached $\sim 60 \%$ during this period [108], indicating a high coverage of forest around the Qinghai Lake basin, which is significant considering that a forest-steppe transition is regarded as the optimal condition for hunting [109]. Moreover, substantial increases in temperature and precipitation during the Bølling-Allerød interval in the Northern Hemisphere might have resulted in rapid population increases in East Asia, as has been indicated by genetic evidence [110], and this also contributed to human expansion into the unpopulated habitats of the TP.

The climate evidently deteriorated during the Younger Dryas, resulting in a sharp drop in the temperature and the intensity of the Asian monsoon, as shown in Figure 5a-c. Forest coverage in Qinghai Lake basin also obviously declined [108]. Although prehistoric humans persisted in occupying middle-altitude areas, such as the Qinghai Lake basin, during the Younger Dryas [111], they also exploited lower-altitude areas such as the northern Yunnan Province and the western Loess Plateau [93-95], which would have been more beneficial to survival during winter. Humans spread upward into areas close to $4000 \mathrm{~m}$ a.s.l. soon after the beginning of the Holocene, at 11,200 cal BP [44], which was related to rapid climatic amelioration and local environmental improvement [112]. Moreover, warmer-wetter conditions seem to have taken hold in the western TP during the early Holocene [113]. The warm-wet climate has also been cited as a major factor in promoting the expansion of human living space in prehistoric times $[114,115]$. This upward expansion seems to have been sustained until the middle Holocene, with the support of favorable climatic-environmental conditions (Figures 4 and 5).

Moreover, human occupation of the TP was suggested to be influenced by both climate change and social evolution after $2000 \mathrm{BP}$ [8]. Hunter-gatherers occupied the TP with greater frequency and intensity in 8700-6000 BP, and they also inhabited the margin of the hinterland of the TP, such as the Yushu area (Figures 4 and 5). Temperature and precipitation on the TP generally remained stable at a high level during this period $[106,116,117]$, providing a favorable living environment in high-altitude areas [108,118]. Moreover, broomcorn and foxtail millets were probably domesticated in 10,000 BP [119,120]. The earliest center for millet cultivation may be eastern Inner Mongolia during the Xinglongwa period (8200-7400 cal BP) [121,122], while millet crop remains have been identified at contemporaneous sites in northern China, such as Cishan [119], Dadiwan [123], and Yuezhuang [124]. These archaeological findings indicate that farming groups began to emerge in the Loess Plateau after the second half of the ninth millennium BP, and this might have compelled hunting-gathering groups to move westward toward the TP, thus also promoting the human occupation of the hinterland in east-central TP in $\sim 8700-6000$ BP (Figures 4b and 5e).

Humans extensively settled areas below $2500 \mathrm{~m}$ a.s.l. in the NETP from 5200 BP [15], and this was mainly promoted by the intensification and expansion of rain-fed agriculture in northern China after the seventh millennium BP [122], as shown in Figure 5d. Millet cultivation became the most important subsistence strategy in the western Loess Plateau at around $~ 5900 \mathrm{BP}$ [125], and this promoted the development and wide expansion of the late Yangshao Culture ( 5500-5000 cal BP) and Majiayao Culture ( 5300-4000 cal BP), as 
well as the spread of millet crops into the eastern TP $[57,126]$. Favorable climate conditions also facilitated cultural development in this period [28,29]. As millets are cold-sensitive crops, and the upper limit for their cultivation in this area has been assessed to be $\sim 2400 \mathrm{~m}$ a.s.l. [127,128], farmers mainly settled below $2500 \mathrm{~m}$ a.s.l. during 5200-3600 BP [15]. The living space of hunter-gatherers also moved downward towards the eastern margin of the $\mathrm{TP}$, into sites such as those at Zongri and Karuo, probably in order to acquire millets from nearby farming groups [99]. This resulted in the absence of human occupation in highaltitude areas during this period. A megadrought event was detected in Central Asia [129], synchronous with the drop in intensity of the Asian monsoon (shown in Figure 5c), and this may have impacted the water supply on the TP, immediately triggering the retreat of hunter-gatherers (Figure 4c). Furthermore, temperatures on the TP in 6000-3600 BP were lower than in 11,500-6000 BP [106,117], which might also be responsible for the downward human migration during this period, as shown in Figure 5.

Prehistoric humans permanently and extensively settled areas above $2500 \mathrm{~m}$ a.s.l. on the TP in around $3600 \mathrm{BP}$, which was mainly facilitated by the adoption of cold-tolerant crops (barley and wheat) and sheep [15], which had initially been domesticated in West Asia $[130,131]$. These western crops and livestock were initially introduced into China in the fifth millennium BP [132], as also shown in Figure 5d, and into the Hexi Corridor in $\sim 4000 \mathrm{BP}$ through the trans-Eurasia cultural exchange [58]. However, humans did not adopt barley as their staple food until 3600 BP in the NETP [133]. Post-3600 BP, an agro-pastoral lifestyle, characterized by raising yak and sheep and cultivating barley, was adopted, which enabled humans to occupy areas such as the eastern Qaidam basin (2500$3500 \mathrm{~m}$ a.s.l.) on the NETP year-round [134,135]. Nevertheless, this kind of subsistence strategy could not support intensive human settlements in areas above $4000 \mathrm{~m}$ a.s.l., where nomadic production is the main component of the livelihood today. A nomadic lifestyle might have been introduced into northwest China in 2800 BP [136], which then probably emerged in the Yushu area in 2700 BP [25]. Domestic animal remains, petroglyphs and cist burials sites have been read as signs of the emergence of a transhumance [137,138], as had frequently been found at archaeological sites in the Yushu area [25], also shown in Figure 1b. This archaeological evidence indicates that humans might have adopted a cold-adaptive nomadic lifestyle, which finally facilitated the permanent occupation of the high-altitude hinterland of the TP during the late Bronze Age.

\section{Conclusions}

Environmental and archaeological studies conducted on the CXGS site reveal that prehistoric human expanded into Yushu area, the eastern margin of the high-altitude hinterland of the TP, during the periods of $\sim 8600-7100 \mathrm{cal} \mathrm{BP}$ and $\sim 2400-2100 \mathrm{cal} \mathrm{BP}$, respectively. This suggests the persistent expansion towards the high-altitude hinterland of the TP by prehistoric hunter-gatherers during the warming early-middle Holocene $(11,500-6000 \mathrm{BP})$.

Early expansion into the high-altitude hinterlands by hunter-gatherers appear to be strongly related to favorable climatic-environmental conditions during the early-middle Holocene. During this period, the environment in the hinterland of the TP was highly suited to hunter-gatherers' activities.

The cooling-drying climate conditions post- $6000 \mathrm{BP}$, and the facilitation of cultural exchange between indigenous hunting-gathering groups and newly emerging agricultural groups in the eastern margin of the TP, are likely responsible for the lack of human occupation of the high-altitude hinterland of the TP. It was not until the fourth millennium BP that the high-altitude hinterland of the TP was reoccupied. The increase in nomadic lifestyle brought about by the prehistoric trans-Eurasia cultural exchange after $2800 \mathrm{BP}$ finally facilitated the permanent settlement of the hinterland of "the roof of the world".

Supplementary Materials: The following are available online at https:/ /www.mdpi.com/article/10 $.3390 /$ su13137065/s1, Table S1: published radiocarbon dates of millets and wheat-barley remains in prehistoric China. 
Author Contributions: Conceptualization, G.H.; formal analysis, M.Q. and Q.W.; funding acquisition, G.H.; investigation, G.H., L.C. and Q.W.; resources, L.C.; supervision, G.H.; visualization, M.Q. and Q.W.; writing — original draft, G.H.; writing-review and editing, M.Q. and W.D. All authors have read and agreed to the published version of the manuscript.

Funding: This research was funded by Natural Science Foundation of Qinghai Province, grant number 2021-ZJ-917; Strategic Priority Research Program of the Chinese Academy of Sciences, Pan-Third Pole Environment Study for a Green Silk Road, grant number XDA2004010101; Qinghai Provincial Project for Thousand Top Innovative Talents.

Data Availability Statement: The data presented in this study are available in the corresponding references.

Acknowledgments: We thank Y. He from Sichuan University for field guidance; N. Jiangcai from Yushu Prefecture Museum for providing data and photos; L. Yang from Qinghai Normal University for fieldwork; C. Oldknow, G. Dong, and R. Li from Lanzhou University for analysis and discussion.

Conflicts of Interest: The authors declare no conflict of interest.

\section{References}

1. Wu, T.Y. Challenge of plateau hypoxia environment to human being. J. Med. Res. 2006, 35, 1-2. (In Chinese)

2. Madsen, D.B.; Ma, H.Z.; Brantingham, P.J.; Gao, X.; Rhode, D.; Zhang, H.Y.; Olsen, J.W. The late Upper Paleolithic occupation of the northern Tibetan Plateau margin. J. Archaeol. Sci. 2006, 33, 1433-1444. [CrossRef]

3. Rhode, D.; Zhang, H.Y.; Madsen, D.B.; Gao, X.; Brantingham, P.J.; Ma, H.Z.; Olsen, J.W. Epipaleolithic/early Neolithic settlements at Qinghai Lake, Western China. J. Archaeol. Sci. 2007, 34, 600-612. [CrossRef]

4. Madsen, D.B.; Perreault, C.; Rhode, D.; Sun, Y.J.; Yi, M.J.; Brantingham, P.J. Early foraging settlement of the Tibetan Plateau highlands. Archaeol. Res. Asia 2017, 11, 15-26. [CrossRef]

5. Bureau of National Cultural Relics. Atlas of Chinese Cultural Relics-Fascicule of Qinghai Province, 1st ed.; China Cartographic Publishing House: Beijing, China, 1996. (In Chinese)

6. Bureau of National Cultural Relics. Atlas of Chinese Cultural Relics-Fascicule of Tibet, 1st ed.; Cultural Relics Publishing House: Beijing, China, 2010. (In Chinese)

7. Su, B.Q. China Ancient Times, 1st ed.; Shanghai People's Publishing House: Shanghai, China, 2010. (In Chinese)

8. Brantingham, P.J.; Gao, X. Peopling of the Northern Tibetan Plateau. World Archaeol. 2006, 38, 387-414. [CrossRef]

9. Zhao, M.; Kong, Q.P.; Wang, H.W.; Peng, M.S.; Xie, X.D.; Wang, W.Z.; Jia, Y.; Duan, J.G.; Cai, M.C.; Zhao, S.N.; et al. Mitochondrial genome evidence reveals successful Late Paleolithic settlement on the Tibetan Plateau. Proc. Natl. Acad. Sci. USA 2009, 106, 21230-21235. [CrossRef] [PubMed]

10. Aldenderfer, M. Peopling the Tibetan plateau: Insights from archaeology. High. Alt. Med. Biol. 2011, 12, 141-147. [CrossRef]

11. Qi, X.B.; Cui, C.Y.; Peng, Y.; Zhang, X.M.; Yang, Z.H.; Zhong, H.; Zhang, H.; Xiang, K.; Cao, X.Y.; Wang, Y.; et al. Genetic evidence of Paleolithic colonization and Neolithic expansion of modern Humans on the Tibetan Plateau. Mol. Biol. Evol. 2013, 30, 1761-1778. [CrossRef]

12. Hou, G.L.; Lai, Z.P.; Cao, G.; Chongyi, E.; Sun, Y.J.; Rhode, D.; James, F. The earliest prehistoric pottery in the Qinghai-Tibetan Plateau and its archaeological implications. Quat. Geochronol. 2015, 30, 431-437. [CrossRef]

13. Lu, D.S.; Lou, H.Y.; Yuan, K.; Wang, X.J.; Wang, Y.C.; Zhang, C.; Lu, Y.; Yang, X.; Deng, L.; Zhou, Y.; et al. Ancestral origins and genetic history of Tibetan highlanders. Am. J. Hum. Gen. 2016, 99, 580-594. [CrossRef]

14. Chen, Y.C.; Hou, G.L.; Chen, X.L.; Gao, J.Y.; Jin, S.M. New perspectives on the Late Pleistocene peopling of the Tibetan Plateau: The core-and-flake industry from the Tongtian River Valley. Antiquity 2021, 95, 587-604. [CrossRef]

15. Chen, F.H.; Dong, G.H.; Zhang, D.J.; Liu, X.Y.; Jia, X.; An, C.B.; Ma, M.M.; Xie, Y.W.; Barton, L.; Ren, X.Y.; et al. Agriculture facilitated permanent human occupation of the Tibetan Plateau after 3600 BP. Science 2015, 347, 248-250. [CrossRef] [PubMed]

16. Meyer, M.C.; Aldenderfer, M.S.; Wang, Z.; Hoffmann, D.L.; Dahl, J.A.; Degering, D.; Haas, W.R.; Schlütz, F. Permanent human occupation of the central Tibetan Plateau in the early Holocene. Science 2017, 355, 64-67. [CrossRef]

17. Zhang, J.F.; Dennell, R. The last of Asia conquered by Homo sapiens. Science 2018, 362, 992-993. [CrossRef]

18. Qiu, J. Who are the Tibetans? Science 2015, 347, 708-711. [CrossRef]

19. Zhang, D.J.; Dong, G.H.; Wang, H.; Ren, X.Y.; Ha, P.P.; Qiang, M.R.; Chen, F.H. History and possible mechanisms of prehistoric human migration to the Tibetan Plateau. Sci. China Earth Sci. 2016, 59, 1-14. [CrossRef]

20. Chen, F.H.; Welker, F.; Shen, C.C.; Bailey, S.E.; Bergmann, I.; Davis, S.; Xia, H.; Wang, H.; Fischer, R.; Freidline, S.E.; et al. A late Middle Pleistocene Denisovan mandible from the Tibetan Plateau. Nature 2019, 569, 409-412. [CrossRef] [PubMed]

21. Zhang, D.J.; Xia, H.; Chen, F.H.; Li, B.; Slon, V.; Cheng, T.; Yang, R.W.; Jacobs, Z.; Dai, Q.Y.; Massilani, D.; et al. Denisovan DNA in Late Pleistocene sediments from Baishiya Karst Cave on the Tibetan Plateau. Science 2020, 370, 584-587. [CrossRef]

22. Zhang, X.L.; Ha, B.B.; Wang, S.J.; Chen, Z.J.; Ge, J.Y.; Long, H.; He, W.; Da, W.; Nian, X.M.; Yi, M.J.; et al. The earliest human occupation of the high-altitude Tibetan Plateau 40 thousand to 30 thousand years ago. Science 2018, 362, 1049-1051. [CrossRef] 
23. Sun, Y.J.; Lai, Z.P.; Long, H.; Liu, X.J.; Fan, Q.S. Quartz OSL dating of archaeological sites in Xiao Qaidam Lake of the NE Qinghai-Tibetan Plateau and its implications for palaeoenvironmental changes. Quat. Geochronol. 2010, 5, 360-364. [CrossRef]

24. Hudson, A.M.; Olsen, J.W.; Quade, J. Radiocarbon dating of interdune paleo-wetland deposits to constrain the age of mid-to-late Holocene microlithic artefacts from the Zhongba site, Southwestern Qinghai-Tibet Plateau. Geoarchaeology 2014, 29 , 33-46. [CrossRef]

25. Ren, L.L.; Dong, G.H.; Li, H.M.; Rhode, D.; Flad, R.K.; Li, G.Q.; Yang, Y.; Wang, Z.X.; Cai, L.H.; Ren, X.Y.; et al. Dating human settlement in the east-central Tibetan Plateau during the Late Holocene. Radiocarbon 2018, 60, 137-150. [CrossRef]

26. Brantingham, P.J.; Gao, X.; Olsen, J.W.; Ma, H.; Rhode, D.; Zhang, H.; Madsen, D.B. A short chronology for the peopling of the Tibetan Plateau. Dev. Quat. Sci. 2007, 9, 129-150.

27. Hou, G.L.; Xu, C.J.; Fan, Q.S. Three expansions of prehistoric humans towards northeast margin of Qinghai-Tibet Plateau and environmental change. Acta Geogr. Sin. 2010, 65, 65-72, (In Chinese with English abstract).

28. Dong, G.H.; Jia, X.; An, C.B.; Chen, F.H.; Zhao, Y.; Tao, S.C.; Ma, M.M. Mid-Holocene climate change and its effect on prehistoric cultural evolution in Eastern Qinghai Province, China. Quat. Res. 2012, 77, 23-30. [CrossRef]

29. Dong, G.H.; Jia, X.; Elston, R.; Chen, F.H.; Li, S.C.; Wang, L.; Cai, L.H.; An, C.B. Spatial and temporal variety of prehistoric human settlement and its influencing factors in the upper Yellow River valley, Qinghai Province, China. J. Archaeol. Sci. 2013, 40, 2538-2546. [CrossRef]

30. Han, F.; He, Y.H.; Du, W.; Cai, L.H.; Lu, H.L. Technological strategy and mobility of Middle Holocene hunter-gatherers in the high-altitude Qinghai-Tibetan Plateau: A case study from Tshem gzhung kha thog. Archaeol. Anthropol. Sci. 2020, 12, 242. [CrossRef]

31. Chan, D.; Wu, Q.G.; Jiang, G.X.; Dai, X.L. Projected shifts in Köppen climate zones over china and their temporal evolution in cmip5 multi-model simulations. Adv. Atmos. Sci. 2016, 33, 283-293. [CrossRef]

32. Liu, M.G. China Nature Geography Atlas, 3rd ed.; China Cartographic Publishing House: Beijing, China, 2010. (In Chinese)

33. Zhang, X.H. Exploring the route to industrialize the agriculture of Yushu Prefecture after the earthquake. China J. Comm. 2012, 21, 252-253. (In Chinese)

34. Bronk Ramsey, C. Bayesian analysis of radiocarbon dates. Radiocarbon 2009, 51, 337-360. [CrossRef]

35. Reimer, P.; Austin, W.; Bard, E.; Bayliss, A.; Blackwell, P.; Bronk Ramsey, C.; Butzin, M.; Cheng, H.; Edwards, R.; Friedrich, M.; et al. The IntCal20 Northern Hemisphere radiocarbon age calibration curve (0-55 cal kBP). Radiocarbon 2020, 62, 725-757. [CrossRef]

36. Connor, S.E.; Thomas, I.; Kvavadze, E.V. A 5600-yr history of changing vegetation, sea levels and human impacts from the Black Sea coast of Georgia. Holocene 2007, 17, 25-36. [CrossRef]

37. Innes, J.B.; Zong, Y.Q.; Chen, Z.Y.; Chen, C.; Wang, Z.H.; Wang, H. Environmental history, palaeoecology and human activity at the early Neolithic forager/cultivator site at Kuahuqiao, Hangzhou, eastern China. Quat. Sci. Rev. 2009, 28, 2277-2294. [CrossRef]

38. Inoue, J.; Okuyama, C.; Takemura, K. Long-term fire activity under the East Asian monsoon responding to spring insolation, vegetation type, global climate, and human impact inferred from charcoal records in Lake Biwa sediments in central Japan. Quat. Sci. Rev. 2018, 179, 59-68. [CrossRef]

39. Clark, J.S. Particle motion and the theory of charcoal analysis: Source area, transport deposition, and sampling. Quat. Res. 1988, 30, 67-80. [CrossRef]

40. Miao, Y.F.; Zhang, D.J.; Cai, X.M.; Li, F.; Jin, H.L.; Wang, Y.P.; Liu, B. Holocene fire on the northeast Tibetan Plateau in relation to climate change and human activity. Quat. Int. 2016, 443, 124-131. [CrossRef]

41. Li, X.Q.; Zhou, X.Y.; Shang, X.; Dodson, J. Different- $\left(\mathrm{kPa} /{ }^{\circ} \mathrm{C}\right)$ size method of charcoal analysis in loess and its significance in the study of fire variation. J. Lake Sci. 2006, 18, 540-544, (In Chinese with English abstract).

42. Brantingham, P.J.; Gao, X.; Madsen, D.B.; Rhode, D.; Perreault, C.; Woerd, J.; Olsen, J.W. Late occupation of the high-elevation Northern Tibetan Plateau based on cosmogenic, luminescence, and radiocarbon ages. Geoarchaeology 2013, 28, 413-431. [CrossRef]

43. Li, G.Q.; Dong, G.H.; Wen, L.J.; Chen, F.H. Overbank flooding and human occupation of the Shalongka site in the Upper Yellow River Valley, northeast Tibet Plateau in relation to climate change since the last deglaciation. Quat. Res. 2014, 82, 354-365. [CrossRef]

44. Hou, G.L.; Cao, G.H.; Chongyi, E.; Ren, X.Y.; Wuennemann, B.; Li, F. New evidence of human activities at an altitude of 4000 meters area of Qinghai-Tibet plateau. Acta Geogr. Sin. 2016, 71, 1231-1240, (In Chinese with English abstract).

45. Gao, J.Y.; Hou, G.L.; Wei, H.C.; Chen, Y.C.; Chongyi, E.; Cheng, X.L.; Lancuo, Z. Prehistoric human activity and its environmental background in Lake Donggi Cona basin, northeastern Tibetan Plateau. Holocene 2020, 30, 657-671. [CrossRef]

46. Chen, Y.C.; Hou, G.L.; Gao, J.Y.; Chongyi, E.; Chen, X.L.; Lancuo, Z. Microblade technology and site structure of the Late Mesolithic hunter-gatherers in Donggi-Cona Lake Basin: New implications for human dispersals and interactions in the northeastern Tibetan Plateau during Holocene. Quat. Int. 2021, 574, 43-51. [CrossRef]

47. Patterson, W.A.; Edwards, K.J.; Maquire, D.J. Microscopic charcoal as a fossil indicator of fire. Quat. Sci. Rev. 1987, 6, 3. [CrossRef]

48. Tang, H.S.; Zhou, C.L.; Li, Y.Q.; Liang, Z. A new discovery of microlithic information at the entrance to the Northern Qingzang Plateau of the Kunlun Mountains of Qinghai. Chin. Sci. Bull. 2013, 58, 247-253, (In Chinese with English abstract).

49. Zhang, D.D.; Li, S.H. Optical dating of Tibetan human hand- and footprints: An implication for the palaeoenvironment of the last glaciation of the Tibetan Plateau. Geophys. Res. Lett. 2002, 29, 16-1-16-3. [CrossRef] 
50. Zhang, D.D.; Li, S.H. Comment on "Permanent human occupation of the central Tibetan Plateau in the early Holocene". Science 2017, 357, eaam9231. [CrossRef] [PubMed]

51. Zhang, D.J.; Zhang, N.M.; Wang, J.; Ha, B.B.; Dong, G.H.; Chen, F.H. Comment on “Permanent human occupation of the central Tibetan Plateau in the early Holocene". Science 2017, 357, eaam8273. [CrossRef] [PubMed]

52. Tibetan Bureau of Cultural Relics. Field Archaeology Report on the Tibet Section of Qingzang Railway, 1st ed.; Science Press: Beijing, China, 2005. (In Chinese)

53. Yao, J.; Huo, W. A preliminary report on investigation of ancient tombs of Piyang-Donggar site in Zhada County, Tibet. Acta Archaeol. Sin. 2001, 6, 14-31, (In Chinese with English abstract).

54. Greenland Ice-Core Project Members. Climate instability during the last interglacial period recorded in the GRIP ice core. Nature 1993, 364, 203-207. [CrossRef]

55. Marcott, S.A.; Mix, A.C. A reconstruction of regional and global temperature for the past 11,300 years. Science 2013, 339, $198-201$. [CrossRef] [PubMed]

56. Dykoski, C.A.; Edwards, R.L.; Cheng, H.; Yuan, D.X.; Cai, Y.J.; Zhang, M.L.; Lin, Y.S.; Qing, J.M.; An, Z.S.; Revenaugh, J. A high-resolution, absolute-dated Holocene and deglacial Asian monsoon record from Dongge cave, China. Earth Planet. Sci. Lett. 2005, 233, 71-86. [CrossRef]

57. Jia, X.; Dong, G.H.; Li, H.; Brunson, K.; Chen, F.H.; Ma, M.M.; Wang, H.; An, C.B.; Zhang, K.R. The development of agriculture and its impact on cultural expansion during the late Neolithic in the Western Loess Plateau, China. Holocene 2013, $23,85-92$. [CrossRef]

58. Long, T.W.; Leipe, C.; Jin, G.Y.; Wagner, M.; Guo, R.Z.; Schröder, O.; Tarasov, P.E. The early history of wheat in China from 14C dating and Bayesian chronological modelling. Nat. Plants 2018, 4, 272-279. [CrossRef] [PubMed]

59. Bestel, S.; Bao, Y.J.; Zhong, H.; Chen, X.C.; Liu, L. Wild plant use and multi-cropping at the early Neolithic Zhuzhai site in the middle Yellow River region, China. Holocene 2017, 28, 195-207. [CrossRef]

60. Chen, T.T.; Jia, X.; Li, H.M.; Dong, G.H. The analysis of spatiotemporal transformations of agricultural and its influence factors during Qijia culture period in Gansu-Qinghai region. Quat. Sci. 2019, 39, 132-144, (In Chinese with English abstract).

61. Chen, T.T.; Qiu, M.H.; Liu, R.L.; Li, H.M.; Hou, H.W.; Howarth, P.; Bowring, S.; Zhou, A.F. Human responses to climate change in the late prehistoric Western Loess Plateau, northwest China. Radiocarbon 2020, 62, 1193-1207. [CrossRef]

62. Crawford, G.W.; Chen, X.X.; Luan, F.S.; Wang, J.H. A preliminary analysis on plant remains of the Yuezhuang site in Changqing District, Jinan City, Shandong Province. Jianghan Archaeol. 2013, 2, 107-116, (In Chinese with English abstract).

63. D'Alpoim Guedes, J. Adaptation and Invention during the Spread of Agriculture to Southwest China. Ph.D. Thesis, Harvard University, Boston, MA, USA, 2013.

64. Deng, Z.H.; Qin, L.; Gao, Y.; Weisskopf, A.; Zhang, C.; Fuller, D.Q. From early domesticated rice of the middle Yangtze Basin to millet, rice and wheat agriculture: Archaeobotanical macro-remains from Baligang, Nanyang Basin, Central China (6700-500 BC). PLoS ONE 2015, 10, e0139885. [CrossRef] [PubMed]

65. Dodson, J.R.; Li, X.Q.; Zhou, X.Y.; Zhao, K.L.; Sun, N.; Atahan, P. Origin and spread of wheat in China. Quat. Sci. Rev. 2013, 72, 108-111. [CrossRef]

66. Dong, G.H.; Wang, Z.L.; Ren, L.L.; Matuzeviciute, G.M.; Wang, H.; Ren, X.Y.; Chen, F.H. A comparative study of 14 C dating on charcoal and charred seeds from Late Neolithic and Bronze Age sites in Gansu and Qinghai Provinces, NW China. Radiocarbon 2014, 56, 157-163. [CrossRef]

67. Flad, R.; Li, S.C.; Wang, X.H.; Zhao, Z.J. Early wheat in China: Results from new studies at Donghuishan in the Hexi Corridor. Holocene 2010, 20, 955-965. [CrossRef]

68. Henan Provincial Institute of Cultural Relics and Archaeology. Sanmenxia Nanjiaokou Site, 1st ed.; Science Press: Beijing, China, 2009. (In Chinese)

69. Institute of Archaeology, Chinese Academy of Social Sciences. Dataset of Radiocarbon Dating in Chinese Archaeology 1965-1991, 1st ed.; Cultural Relics Press: Beijing, China, 1992. (In Chinese)

70. Jia, X.; Sun, Y.J.; Wang, L.; Sun, W.F.; Zhao, Z.J.; Lee, H.F.; Huang, W.B.; Wu, S.Y.; Lu, H.Y. The transition of human subsistence strategies in relation to climate change during the Bronze Age in the West Liao River Basin, Northeast China. Holocene 2016, 26, 781-789. [CrossRef]

71. Jiang, H.E.; Zhang, Y.B.; Lu, E.G.; Wang, C.S. Archaeobotanical evidence of plant utilization in the ancient Turpan of Xinjiang, China: A case study at the Shengjindian cemetery. Veg. Hist. Archaeobot. 2015, 24, 165-177. [CrossRef]

72. Jin, G.Y.; Wagner, M.; Tarasov, P.E.; Wang, F.; Liu, Y.C. Archaeobotanical records of middle and late Neolithic agriculture from Shandong Province, East China, and a major change in regional subsistence during the Dawenkou Culture. Holocene 2016, 26, 1605-1615. [CrossRef]

73. Lee, G.A.; Bestel, S.H. Contextual analysis of plant remains at the Erlitou-period Huizui site, Henan, China. Bull. Indo Pac. Prehist. Assoc. 2007, 27, 49-60.

74. Lee, G.A.; Crawford, G.W.; Liu, L.; Chen, X.C. Plants and people from the early Neolithic to Shang periods in North China. Proc. Natl. Acad. Sci. USA 2007, 104, 1087-1092. [CrossRef]

75. Li, C.X. Molecular Genetic Analysis of Ancient Remains from Xiaohe Cemetery. Ph.D. Thesis, Jilin University, Changchun, China, 2010. (In Chinese with English abstract).

76. Li, K.S.; Min, R. Study on Early Bronze Age in Yunnan Province. Thinking 2011, 4, 100-105. (In Chinese) 
77. Li, X.Q.; Zhou, X.Y.; Zhou, J.; Dodson, J.; Zhang, H.B.; Shang, X. The earliest archaeobiological evidence of the broadening agriculture in China recorded at Xishanping site in Gansu Province. Sci. China Earth Sci. 2007, 50, 1707-1714. [CrossRef]

78. Liu, X.Y.; Lister, D.L.; Zhao, Z.J.; Staff, R.A.; Jones, P.J.; Zhou, L.P.; Pokharia, A.K.; Petrie, C.A.; Pathak, A.; Lu, H.L.; et al. The virtues of small grain size: Potential pathways to a distinguishing feature of Asian wheats. Quat. Int. 2016, 426, 107-119. [CrossRef]

79. Panel of Xia-Shang-Zhou Chronology Project. Report of Xia-Shang-Zhou Chronology Project 1996-2000, 1st ed.; World Publishing Corporation: Beijing, China, 2001. (In Chinese)

80. Qiu, Z.W.; Yang, Y.M.; Shang, X.; Li, W.Y.; Abuduresule, Y.; Hu, X.J.; Pan, Y.; Ferguson, D.K.; Hu, Y.W.; Wang, C.S.; et al. Paleo-environment and paleo-diet inferred from early Bronze Age cow dung at Xiaohe cemetery, Xinjiang, NW China. Quat. Int. 2014, 349, 167-177. [CrossRef]

81. Peking University Radiocarbon laboratory. Report on radiocarbon dating. Cult. Rel. 1996, 6, 91-95. (In Chinese)

82. Ren, L.L.; Yang, Y.; Wang, Q.Q.; Zhang, S.J.; Chen, T.T.; Cui, Y.F.; Wang, Z.X.; Liang, G.J.; Dong, G.H. The transformation of cropping patterns from Late Neolithic to Early Iron Age (5900-2100 BP) in the Gansu-Qinghai region of northwest China. Holocene 2020, 31, 183-193. [CrossRef]

83. Wang, X.; Fuller, B.T.; Zhang, P.C.; Hu, S.M.; Hu, Y.W.; Shang, X. Millet manuring as a driving force for the late Neolithic agricultural expansion of North China. Sci. Rep. 2018, 8, 5552. [CrossRef]

84. Wang, X.; Shang, X.; Jiang, H.E.; Zhang, P.E.; Wang, W.L.; Wang, C.S. Preliminary analysis of floral remains from the Nanshantou and Muwanghe site in Baishui, Shannxi Province. Archaeol. Cult. Rel. 2015, 2, 100-104, (In Chinese with English abstract).

85. Wang, Y.Q.; Yuan, X.; Ruan, Q.R. Preliminary understanding of Jirentaigoukou site in Nilka County, Xinjiang after the archaeological excavation in 2015-2018. W. Reg. Stud. 2019, 1, 133-138. (In Chinese)

86. Yang, R.P.; Yang, Y.M.; Li, W.Y.; Abuduresule, Y.; Hu, X.J.; Wang, C.S.; Jiang, H.E. Investigation of cereal remains at the Xiaohe Cemetery in Xinjiang, China. J. Archaeol. Sci. 2014, 49, 42-47. [CrossRef]

87. Yang, L.; Ma, M.M.; Chen, T.T.; Cui, Y.F.; Chen, P.P.; Zheng, L.C.; Lu, P. How did trans-Eurasian exchanges affect spatial-temporal variation in agricultural patterns during the late prehistoric period in the Yellow River valley (China)? Holocene 2020, 31, $247-257$. [CrossRef]

88. Yuan, S.X.; Chen, T.M.; Ma, L.; Meng, Q.P. Report on radiocarbon dating, VII. Cult. Rel. 1987, 11, 89-92. (In Chinese)

89. Zhang, G.L.; Wang, S.Z.; Ferguson, D.K.; Yang, Y.M.; Liu, X.Y.; Jiang, H.E. Ancient plant use and palaeoenvironmental analysis at the Gumugou cemetery, Xinjiang, China: Implication from desiccated plant remains. Archaeol. Anthropol. Sci. 2017, 9, 145-152. [CrossRef]

90. Zhang, J.N.; Xia, Z.K.; Zhang, X.H. Research on charred plant remains from the Neolithic to the Bronze Age in Luoyang Basin. Chin. Sci. Bull. 2014, 59, 3388-3397, (In Chinese with English abstract). [CrossRef]

91. Zhou, X.Y.; Li, X.Q.; Dodson, J.; Zhao, K.L. Rapid agricultural transformation in the prehistoric Hexi Corridor, China. Quat. Int. 2016, 426, 33-41.

92. Zhou, X.Y.; Yu, J.J.; Spengler, R.N.; Shen, H.; Zhao, K.L.; Ge, J.Y.; Bao, Y.G.; Liu, J.C.; Yang, Q.J.; Chen, G.H.; et al. 5,200-year-old cereal grains from the eastern Altai Mountains redate the trans-Eurasian crop exchange. Nat. Plants 2020, 6, 78-87. [CrossRef]

93. Yang, Z.C. Archeological remains from Dabanqiao cave site, Kunming, Yunnan. Acta Anthropol. Sin. 1993, 12, 305-318, (In Chinese with English abstract).

94. $\mathrm{Hu}$, S.J. Paleoliths excavated in Zhangkou cave, Jiuxiang, Yiliang County. Acta Anthropol. Sin. 1995, 14, 21-31, (In Chinese with English abstract).

95. Bettinger, R.L.; Barton, L.; Morgan, C.; Chen, F.H.; Wang, H.; Guilderson, T.P.; Ji, D.X.; Zhang, D.J. The transition to agriculture at Dadiwan, People's Republic of China. Curr. Anthropol. 2010, 51, 703-714. [CrossRef]

96. Bureau of National Cultural Relics. Atlas of Chinese Cultural Relics-Fascicule of Yunnan Province, 1st ed.; Cultural Relics Publishing House: Beijing, China, 2001. (In Chinese)

97. Bureau of National Cultural Relics. Atlas of Chinese Cultural Relics-Fascicule of Sichuan Province, 1st ed.; Cultural Relics Publishing House: Beijing, China, 2009. (In Chinese)

98. Chen, H.H.; Ge, S.B.; Li, G.L. Discuss to the nature of Zongri relic. Archaeology 1998, 19, 23-27, (In Chinese with English abstract).

99. D'Alpoim Guedes, J. Did foragers adopt farming? A perspective from the margins of the Tibetan Plateau. Quat. Int. 2018, 489, 91-100. [CrossRef]

100. Dong, G.H.; Li, R.; Lu, M.X.; Zhang, D.J.; James, N. Evolution of human-environmental interactions in China from the Late Paleolithic to the Bronze Age. Prog. Phys. Geogr. 2020, 44, 233-250. [CrossRef]

101. Li, S.C. The origin and diffusion of cist burials, take China as the example. Sichuan Cult. Relics 2011, 6, 64-69. (In Chinese)

102. Xie, D.J. Prehistorical Archaeology of Gansu and Qinghai Provinces, 1st ed.; Cultural Relics Press: Beijing, China, 2002. (In Chinese)

103. Liu, X.J.; Cong, L.; Li, X.Z.; Madsen, D.; Wang, Y.X.; Liu, Y.G.; Peng, J. Climate conditions on the Tibetan Plateau during the Last Glacial Maximum and implications for the survival of Paleolithic foragers. Front. Phys. Geogr. 2020, 8, 606051.

104. Rademaker, K.; Hodgins, G.; Moore, K.; Zarrillo, S.; Miller, C.; Bromley, G.R.; Leach, P.; Reid, D.A.; Álvarez, W.Y.; Sandweiss, D.H. Paleoindian settlement of the high-altitude Peruvian Andes. Science 2014, 346, 466-469. [CrossRef]

105. Núñez, L.; Loyola, R.; Cartajena, I.; López, P.; Santander, B.; Maldonado, A.; Souza, P.D.; Carrasco, C. Miscanti-1: Human occupation during the arid Mid-Holocene event in the high-altitude lakes of the Atacama Desert, South America. Quat. Sci. Rev. 2018, 181, 109-122. [CrossRef] 
106. Hou, J.Z.; Huang, Y.S.; Zhao, J.T.; Liu, Z.H.; Colman, S.; An, Z.S. Large Holocene summer temperature oscillations and impact on the peopling of the northeastern Tibetan Plateau. Geophys. Res. Let. 2016, 43, 1323-1330. [CrossRef]

107. Hou, J.Z.; D'Andrea, W.J.; Wang, M.D.; He, Y.; Liang, J. Influence of the Indian monsoon and the subtropical jet on climate change on the Tibetan Plateau since the late Pleistocene. Quat. Sci. Rev. 2017, 163, 84-94. [CrossRef]

108. Shen, J.; Liu, X.Q.; Wang, S.M.; Matsumoto, R. Palaeoclimatic changes in the Qinghai Lake area during the last 18,000 years. Quat. Int. 2005, 136, 131-140.

109. Chen, S.Q. Modeling hunter-gatherers of China. Acta Anthropol. Sin. 2006, 25, 42-55, (In Chinese with English abstract).

110. Zheng, H.X.; Yan, S.; Qin, Z.D.; Jin, L. MtDNA analysis of global populations support that major population expansions began before Neolithic Time. Sci. Rep. 2012, 2, 745. [CrossRef]

111. Rhode, D.; Brantingham, P.J.; Perreault, C.; Madsen, D.B. Mind the gaps: Testing for hiatuses in regional radiocarbon date sequences. J. Archaeol. Sci. 2014, 52, 567-577. [CrossRef]

112. Saini, J.; Günther, F.; Aichner, B.; Mischke, S.; Herzschuh, U.; Zhang, C.J.; Mäusbacher, R.; Gleixner, G. Climate variability in the past $\sim 19,000 \mathrm{yr}$ in NE Tibetan Plateau inferred from biomarker and stable isotope records of Lake Donggi Cona. Quat. Sci. Rev. 2017, 157, 129-140. [CrossRef]

113. Liu, X.J.; Zhang, X.J.; Lin, Y.L.; Jin, L.Y.; Chen, F.H. Strengthened Indian summer monsoon brought more rainfall to the western Tibetan Plateau during the early Holocene. Sci. Bull. 2019, 64, 1482-1485. [CrossRef]

114. Timmermann, A.; Friedrich, T. Late Pleistocene climate drivers of early human migration. Nature 2016, 538, 92-95. [CrossRef]

115. Dong, G.H.; Liu, F.W.; Chen, F.H. Environmental and technological effects on ancient social evolution at different spatial scales. Sci. China Earth Sci. 2017, 60, 2067-2077. [CrossRef]

116. An, Z.S.; Colman, S.M.; Zhou, W.J.; Li, X.Q.; Brown, E.T.; Jull, A.J.T.; Cai, Y.J.; Huang, Y.S.; Lu, X.F.; Chang, H.; et al. Interplay between the westerlies and Asian monsoon recorded in Lake Qinghai sediments since $32 \mathrm{ka}$. Sci. Rep. 2012, 2, 619. [CrossRef]

117. Zhao, C.; Liu, Z.H.; Rohling, E.J.; Yu, Z.C.; Liu, W.G.; He, Y.X.; Zhao, Y.; Chen, F.H. Holocene temperature fluctuations in the northern Tibetan Plateau. Quat. Res. 2013, 80, 55-65. [CrossRef]

118. Miehe, G.; Miehe, S.; Kaiser, K.; Reudenbach, C.; Behrendes, L.; La, D.; Schlütz, F. How old is pastoralism in Tibet? An ecological approach to the making of a Tibetan landscape. Palaeogeogr. Palaeoclimatol. Palaeoecol. 2009, 276, 130-147. [CrossRef]

119. Lu, H.Y.; Zhang, J.P.; Liu, K.; Wu, N.Q.; Li, Y.M.; Zhou, K.S.; Ye, M.L.; Zhang, T.Y.; Zhang, H.J.; Yang, X.Y.; et al. Earliest domestication of common millet (Panicum miliaceum) in East Asia extended to 10,000 years ago. Proc. Natl. Acad. Sci. USA 2009, 106, 7367-7372. [CrossRef]

120. Zhao, Z.J. New archaeobotanic data for the study of the origins of agriculture in China. Curr. Anthropol. 2011, 52, S295-S306. [CrossRef]

121. Liu, X.Y.; Jones, M.K.; Zhao, Z.J.; Liu, G.X.; O'Connell, T.C. The earliest evidence of millet as a staple crop: New light on Neolithic foodways in north China. Am. J. Phys. Anthropol. 2012, 149, 283-290. [CrossRef] [PubMed]

122. Dong, G.H.; Zhang, S.J.; Yang, Y.S.; Chen, J.H.; Chen, F.H. Agricultural intensification and its impact on environment during Neolithic age in Northern China. Chin. Sci. Bull. 2016, 61, 2913-2925, (In Chinese with English abstract). [CrossRef]

123. Zhang, D.J.; Chen, F.H.; Bettinger, R.L.; Barton, L.; Ji, D.X.; Morgan, C.; Wang, H.; Cheng, X.Z.; Dong, G.H.; Guilderson, T.P.; et al. Archaeological records of Dadiwan in the past $60 \mathrm{ka}$ and the origin of millet agriculture. Chin. Sci. Bull. 2010, 55, 1636-1642. [CrossRef]

124. Crawford, G.W.; Chen, X.; Luan, F.; Wang, J. People and plant interaction at the Houli Culture Yuezhuang site in Shandong Province, China. Holocene 2016, 26, 1594-1604. [CrossRef]

125. Barton, L.; Newsome, S.D.; Chen, F.H.; Wang, H.; Guilderson, T.P.; Bettinger, R.L. Agricultural origins and the isotopic identity of domestication in northern China. Proc. Natl. Acad. Sci. USA 2009, 106, 5523-5528. [CrossRef] [PubMed]

126. Dong, G.H.; Yang, Y.S.; Han, J.Y.; Hui, W.; Chen, F.H. Exploring the history of cultural exchange in prehistoric Eurasia from the perspectives of crop diffusion and consumption. Sci. China Earth Sci. 2017, 60, 1110-1123. [CrossRef]

127. Wang, X.Y. Zhongguo Shuji (Common Millet in China), 1st ed.; China Agricultural Press: Beijing, China, 1996. (In Chinese)

128. Chai, Y. Meizi (Commen Millet), 1st ed.; China Agricultural Press: Beijing, China, 1999. (In Chinese)

129. Tan, L.C.; Dong, G.H.; An, Z.S.; Edwards, R.L.; Li, H.M.; Li, D.; Spengler, R.; Cai, Y.J.; Cheng, H.; Lan, J.H.; et al. Megadrought and cultural exchange along the proto-silk road. Sci. Bull. 2021, 66, 603-611. [CrossRef]

130. Zeder, M.A.; Hesse, B. The initial domestication of goats (Capra hircus) in the Zagros Mountains 10,000 years ago. Science 2000, 287, 2254-2257. [CrossRef] [PubMed]

131. Riehl, S.; Zeidi, M.; Conard, N.J. Emergence of agriculture in the foothills of the Zagros Mountains of Iran. Science 2013, 341, 65-67. [CrossRef]

132. Dong, G.H.; Yang, Y.S.; Liu, X.Y.; Li, H.M.; Cui, Y.F.; Wang, H.; Chen, G.K.; Dodson, J.; Chen, F.H. Prehistoric trans-continental cultural exchange in the Hexi Corridor, Northwest China. Holocene 2018, 28, 621-628. [CrossRef]

133. Ma, M.M.; Dong, G.H.; Jia, X.; Wang, H.; Cui, Y.F.; Chen, F.H. Dietary shift after 3600 cal yr BP and its influencing factors in northwestern China: Evidence from stable isotopes. Quat. Sci. Rev. 2016, 145, 57-70. [CrossRef]

134. Dong, G.H.; Ren, L.L.; Jia, X.; Liu, X.Y.; Dong, S.M.; Li, H.M.; Wang, Z.X.; Xiao, Y.M.; Chen, F.H. Chronology and subsistence strategy of Nuomuhong culture in the Tibetan Plateau. Quat. Int. 2016, 426, 42-49. [CrossRef]

135. Huang, X.Z.; Liu, S.S.; Dong, G.H.; Qiang, M.R.; Bai, Z.J.; Zhao, Y.; Chen, F.H. Early human impacts on vegetation on the northeastern Qinghai-Tibetan Plateau during the middle to late Holocene. Prog. Phys. Geogr. 2017, 41, 286-301. [CrossRef] 
136. Kuzmina, E.E. The Prehistory of the Silk Road, 1st ed.; University of Pennsylvania Press: Philadelphia, PA, USA, 2008.

137. Wang, J.X.; Xi, L. An archaeological study of settlements of the early nomadic culture in the Eastern Tianshan mountain region. Archaeology 2009, 1, 28-37. (In Chinese with English abstract).

138. Huo, W. The archaeological exploration on the early settlements of nomadic cultures in Tibet. Archaeology 2014, 14, 151-154. (In Chinese with English abstract). [CrossRef] 